
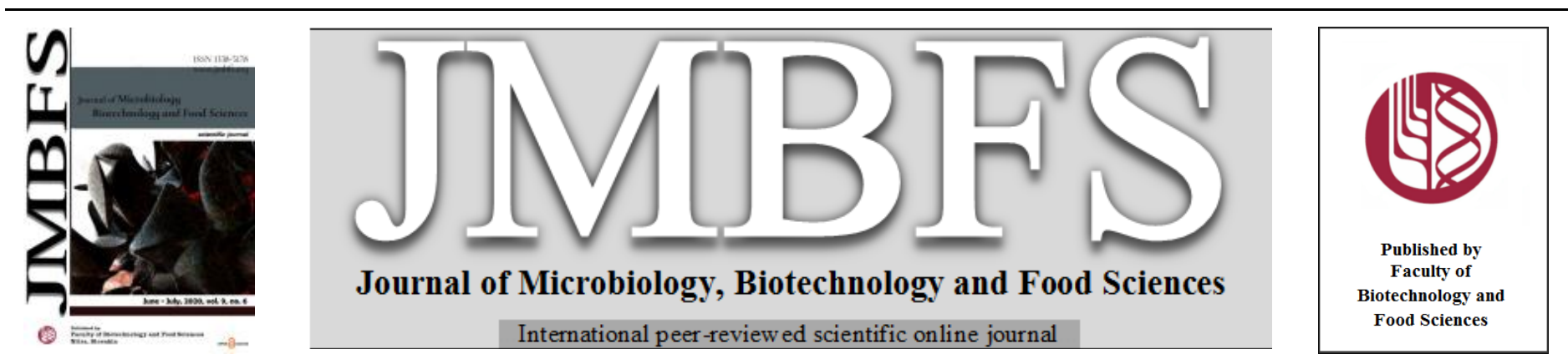

\title{
EVALUATION OF LACTOBACILLUS PARACASEI LP11 AND LACTOBACILLUS RHAMNOSUS 64 POTENTIAL AS CANDIDATES FOR USE AS PROBIOTICS IN FUNCTIONAL FOODS
}

\author{
Fernando Eustáquio de Matos-Jr ${ }^{1,2 *}$; Tizá Teles Santos ${ }^{3}$; Patricia Burns ${ }^{4}$; Jorge Reinheimer ${ }^{4}$; Gabriel Vinderola ${ }^{4}$, Carmen Sílvia \\ Fávaro Trindade
}

\begin{abstract}
Address(es):
${ }_{1}^{1}$ Universidade de São Paulo, Faculdade de Zootecnia e Engenharia de Alimentos, Av. Duque de Caxias Norte, 225, CP 23, CEP: 13535 900, Pirassununga, São Paulo, Brasil.

${ }^{2}$ Universidade Federal de Juiz de Fora, Instituto de Ciências da Vida, Departamento de Nutrição, R. São Paulo, 745, CEP: 35010-180, Governador Valadares, MG, Brasil.

${ }^{3}$ Universidade Estadual de Santa Cruz (UESC), Departamento de Ciências Biológicas, Laboratório de Microbiologia da Agroindústria, Campus Soane Nazaré de Andrade Salobrinho, Rodovia Jorge Amado, KM 16, CEP: 45662-900, Ilhéus, Bahia, Brasil.

${ }^{4}$ Instituto de Lactología Industrial (INLAIN, UNL-CONICET), Facultad de Ingeniería Química, Universidad Nacional del Litoral, Santa Fe, Argentina
\end{abstract}

*Corresponding author: fernando.eustaquio@ufjf.edu.br

doi: 10.15414/jmbfs.2020.9.6.1126-1133

ARTICLE INFO

Received 20. 12. 2018

Revised 27. 1. 2020

Accepted 4. 2. 2020

Published 1. 6. 2020

Regular article

open $\mathcal{O}$ access

\begin{abstract}
Desirable characteristics for probiotic microorganisms were evaluated in Lactobacillus rhamnosus 64 and Lactobacillus paracasei LP11. Both strains were tested for resistance to lysozyme and simulated gastrointestinal fluids, determination of cell wall hydrophobicity, evaluation of antibiotic susceptibility, antagonist activity against pathogens and the ability to use prebiotics. The safety determination was performed by an in vivo test, where the occurrence of bacterial translocation to liver was evaluated after daily oral administration of the strains for 10 days to mice. All results were promising, with the exception of resistance to simulated gastrointestinal fluids, that was unsatisfactory, with a decrease in viable cell concentrations of up to $5.08 \log \mathrm{CFU} / \mathrm{mL}$. The hydrophobicity profile of the strains ranged between 8.47 and $19.19 \%$. Both showed satisfactiry resistance to lysozyme, with survival rates above 80\%, strains were able to antagonize Escherichia coli V517, Salmonella enteritidis OMS-Ca, Staphylococcus aureus 76 and Listeria monocytogenes ATCC 15313, and displayed satisfactory use of lactulose, inulin and P95 raftilose as prebiotics. No bacterial translocation was observed after the administration of the strains to mice. The results obtained herein justify the use of L. rhamnosus 64 and $L$. paracase $\mathrm{LP} 11$ in new investigations for the future application of these microorganisms as probiotics.
\end{abstract}

Keywords: Lactobacilli; Safety; Resistance to gastrointestinal fluids; Hydrophobicity; prebiotics

\section{INTRODUCTION}

Functional foods currently represent a significant portion of the food market (Siró, Kápolna, Kápolna, \& Lugasi, 2008). It is believed that the growth of the functional food market is related to increasing population awareness about the close relationship between food and health (Lähteenmäki, 2013). Functional foods present bioactive components in their composition capable of optimizing the metabolic and/or physiological functioning of the organism, resulting in disease prevention, especially chronic non-degenerative diseases (Gul, Singh, \& Jabeen, 2016; Tur \& Bibiloni, 2016). Among components that give food functional classifications are antioxidant vitamins, phytosterol, omega 3, fiber, prebiotics and probiotics (Dias, Botrel, Fernandes, \& Borges, 2017; Schieber, 2012).

Probiotics are living microorganisms that, when administered in suitable amounts, confer benefits to host health (FAO/WHO, 2002). The main genera used as probiotics are Lactobacillus and Bifidobacterium (Sharma \& Devi, 2014). When ingested in sufficient amounts, probiotics present benefits through a variety of mechanisms, including decreases in the number of pathogenic microorganisms through competitive exclusion (competition for binding sites and nutrients) and bacteriocin production (Niamah, 2010; Hegarty et al., 2016), stimulation of the immune system (Ashraf \& Shah, 2014; Castillo, de Moreno de LeBlanc, Galdeano, \& Perdigón, 2012), vitamin synthesis (LeBlanc et al., 2011), production of short chain fatty acids (acetate, propionate and butyrate) through fiber fermentation (Gibson, 2004), and lactose digestion, reducing the effects of lactose intolerance (Staudacher, 2015).

Currently, probiotic-containing foods represent an important share of the functional food market (Begum et al., 2017), with emphasis on the dairy industry (Granato, Branco, Cruz, Faria, \& Shah, 2010; Vijaya Kumar, Vijayendra, \& Reddy, 2015). The development of these foods involves several challenges. The microorganism must be capable of surviving the adverse conditions inherent to food product processing and storage (Champagne, Gardner, \& Roy, 2005). However, before planning the development of probiotic-containing food, challenges involving the proper selection of these microorganisms must be overcome. A series of criteria involving safety, functional and technological characteristics must be met for a microorganism to be considered probiotic (Mattila-Sandholm et al., 2002).

Probiotic selection begins with the precise identification of the microorganism at the genus, species and strain levels. It is recommended that the microorganism be of human origin, due to the greater propensity to adapt to the human intestine, also considering, the greater possibility of adhesion to intestinal epithelial cells (FAO/WHO, 2002; Shewale, Sawale, Khedkar, \& Singh, 2014). The microorganism must be completely safe for human ingestion, with a nonpathogenic history and no antibiotic resistance gene transfer capabilities (FAO/WHO, 2002; Havenaar, Brink, \& Huis In 't Veld, 1992). In addition, the probiotic candidate must be able to withstand the adverse conditions of the gastrointestinal tract, including contact with gastric acid and bile acids in the stomach and intestine, respectively (Tuomola, Crittenden, Playne, Isolauri, \& Salminen, 2001). It is important that the microorganism display the ability to colonize the human intestine, albeit transiently, through adhesion to the intestinal epithelium (FAO/WHO, 2002; Shewale, Sawale, Khedkar, \& Singh, 2014). Finally, probiotics are expected to exhibit antimicrobial activity against potentially pathogenic bacteria, resistance to antibiotics and be capable of stimulating the host's immune system (Saarela, Mogensen, Fondén, Mättö, \& Mattila-Sandholm, 2000). After fulfilling these criteria, in vivo tests are applied to determine the possible beneficial effects on the maintenance or recovery of human health. 
Considering that microorganism characterization is indispensable for the adequate development of functional foods, the aim of the present study was to evaluate the potential of Lactobacillus paracasei LP11 and Lactobacillus rhamnosus 64 as probiotic candidates by in vitro and in vivo tests.

\section{MATERIAL AND METHODS}

\section{Microorganisms}

Frozen culture of commercial probiotic (Lactobacillus paracasei LP11) was obtained from local provider. Lactobacillus rhamnosus 64 isolated from newborn human feces (Vinderola et al., 2008), were evaluated herein. Before each analysis, freeze-dried L. paracasei LP11 and L. rhamnosus 64 frozen in MRS broth (de Man, Rogosa and Sharpe) were activated in MRS broth (Biokar, Beauvais, France) during $16 \mathrm{~h}$ at $37{ }^{\circ} \mathrm{C}$ under aerobic conditions. The identity of frozen culture of commercial probiotic manufacturer has been kept undisclosed for confidentiality reasons.

\section{Resistance to lysozyme}

The lysozyme resistance analysis was performed as described by Vizoso Pinto, et al. (2006) and Zago et al. (2011) with modifications. Microorganisms grown overnight in $10 \mathrm{ml}$ of MRS broth at $37^{\circ} \mathrm{C}$ were centrifuged, washed twice and resuspended in $2 \mathrm{ml}$ of phosphate buffer $(0.1 \mathrm{M}, \mathrm{pH} 7.0)$. Subsequently, $10 \%$ of the bacterial suspension was inoculated into a sterile electrolytic solution (SEE) (SEE; $0.22 \mathrm{~g} / 1 \mathrm{CaCl}_{2}, 6,2 \mathrm{~g} / 1 \mathrm{NaCl}, 2.2 \mathrm{~g} / 1 \mathrm{KCl}, 1.2 \mathrm{~g} / \mathrm{N} \mathrm{NaHCO}_{3}$ ) in the presence of $100 \mathrm{mg} / 1$ lysozyme (Sigma-Aldrich). The control comprised the bacteria suspension inoculated into the SEE without lysozyme. Survival rates were calculated as a percentage of $\mathrm{CFU} / \mathrm{ml}$ after 30 and 120 min compared to the counts determined at time zero.

\section{Resistance to simulated gastrointestinal fluids}

The in vitro evaluation of the resistance of free microorganisms to simulated gastric fluid (SGF) and simulated intestinal fluids (SIF) was performed according to the method described by Gbassi et al. (2009). The SGF was composed of $9 \mathrm{~g} / \mathrm{L}$ sodium chloride (Synth, Diadema, Brazil) and $3 \mathrm{~g} / \mathrm{l}$ pig stomach pepsin (SigmaAldrich, St. Louis, USA) in distilled water with $\mathrm{pH}$ adjusted to 1.8 with hydrochloric acid. The SIF was prepared with $9 \mathrm{~g} / \mathrm{L}$ sodium chloride (Synth, Diadema, Brazil), $10 \mathrm{~g} / \mathrm{L}$ pancreatin, $9 \mathrm{~g} / \mathrm{L}$ bovine trypsin (Sigma-Aldrich, St. Louis, MO, USA), and $3 \mathrm{~g} / \mathrm{L}$ of bile salts (Oxgall, Difco, Hampshire, UK) in distilled water and $\mathrm{pH}$ adjusted to 6.5 with sodium hydroxide. The microorganisms were inoculated into the SGF and maintained at $37^{\circ} \mathrm{C}$ under agitation. Viable cell counts were performed in MRS at 0,60 and 120 minutes. Subsequently the remaining SGF analysis material was inoculated into the SIF, proceeding with appropriate $\mathrm{pH}$ control and adjustment and viable cell counts in MRS after 0,90 and 180 minutes.

\section{Hydrophobicity}

Strains were grown in $10 \mathrm{~mL}$ of MRS broth for $16 \mathrm{~h}$ at $37{ }^{\circ} \mathrm{C}$. Cultures were centrifuged $(6,000 \mathrm{rpm}, 6 \mathrm{~min})$ and washed twice with phosphate buffer $(0.1 \mathrm{M}$ $\mathrm{pH}$ 7.0). The cultures were then suspended in the same buffer, and the optical density (OD) adjusted to approximately 1.0 at $560 \mathrm{~nm}$. Subsequently, $0.6 \mathrm{ml}$ of $\eta$ hexadecane (Sigma-Aldrich, St. Louis, USA) were added to $3.0 \mathrm{ml}$ of the bacterial suspension and, after homogenization for 2 minutes by vortexing, the mixtures were incubated at $37^{\circ} \mathrm{C}$, for 1 hour, for phase separation. The lower aqueous phases were carefully removed with a sterile Pasteur pipette and absorbances (A1) were recorded at $560 \mathrm{~nm}$ following the method described by Vinderola and Reinheimer (2003) and Duary et al. (2011). The following formula was applied to determine the results, expressed as percentage of bacterial adhesion to the solvent:

$H \%=(1-A 1 / A 0) \times 100 \quad(1)$

Where A0 is the initial adjusted absorbance and A1 is the absorbance of the lower aqueous phase resulting of the $\eta$-hexadecane addition to the bacterial suspension.

\section{Antibiotic susceptibility}

The two strains were submitted to a sensitivity analysis for eight antibiotics (Laboclin, Pinhais, Brazil): cefepime (30 $\mu \mathrm{g})$, cefoxitin $(30 \mu \mathrm{g})$, ceftriaxone (30 $\mu \mathrm{g})$, erythromycin $(15 \mu \mathrm{g})$, neomycin $(30 \mu \mathrm{g})$, penicillin $(10 \mu \mathrm{g})$, tetracycline $(30$ $\mu \mathrm{g})$ and vancomycin $(30 \mu \mathrm{g})$. Susceptibility was determined according to the Kirby \& Bauer method described in Bauer, Kirby, Sherris, \& Turck (1966). A $10^{8}$ $\mathrm{CFU} / \mathrm{mL}$ suspension of each strain was seeded on plates containing MRS agar Subsequently, paper disks embedded with each antibiotic were placed on the surface of the culture medium and the plates were then incubated for $48 \mathrm{~h}$ at 37 ${ }^{\circ} \mathrm{C}$. After incubation, the inhibitory halos formed on each disk were measured with the aid of a pachymeter. The results were qualitatively analyzed, and the microorganisms were classified as sensitive, moderately sensitive or resistant to the evaluated antibiotic.

\section{In vitro antagonism}

The agar spot method was adopted to evaluate the in vitro antagonistic activity of the two lactobacilli strains (Schillinger \& Lücke, 1987). Four pathogens $\left(10^{7}\right.$ $\mathrm{CFU} / \mathrm{ml}$ ) were used, namely Escherichia coli V517, Salmonella enteritidis OMS$\mathrm{Ca}$, Staphylococcus aureus 76 and Listeria monocytogenes ATCC 15313. Additionally, the ability of the neutralized cell-free supernatant to promote an antagonistic effect was assessed according to the methodology proposed by Uhlman, Schillinger, Rupnow, \& Holzapfel (1992) and detailed by Vizoso Pinto et al., (2006). Briefly, the supernatants were obtained from the overnight culture of $L$. paracasei LP11 and L. rhamnosus 64 in MRS broth maintained at $37^{\circ} \mathrm{C}$ in aerobic conditions. After culturing, the cultures were centrifuged at $7,200 \times \mathrm{g}$ for 10 minutes, neutralized with a sterile $5 \mathrm{M} \mathrm{NaOH}$ solution and the supernatants were boiled for 5 min to inactivate viable cells.

\section{Prebiotic use}

The capacity to use inulin, polydextrose, fructooligosaccharides and lactulose was evaluated, according to Zago et al. (2011). Glucose (Sigma-Aldrich) was used as a positive control. Initially, all prebiotics and glucose were solubilized in distilled water and sterilized by filtration. The strains were inoculated $(1.5 \%$ inoculum; $10^{6} \mathrm{CFU} / \mathrm{ml}$ )) into test tubes containing $3 \mathrm{ml}$ of modified MRS broth, which contained $2 \%$ of each of the four prebiotics or glucose as the sole carbon source. The tubes were incubated at $37^{\circ} \mathrm{C}$ for $24 \mathrm{~h}$ under aerobic conditions. The use of prebiotics and glucose was evaluated by measuring the optical density of each culture at $560 \mathrm{~nm}$ (OD560). The cell growth rate in the presence of each prebiotic was calculated according to the following formula:

\section{Growth rate $=[((\mathrm{MRSp}-\mathrm{MRSb}) * 100) /(\mathrm{MRSg}-\mathrm{MRSb})] \quad(2)$}

Where MRSp is the MRS containing each prebiotic, MRSb is the MRS without a carbon source (negative control) and MRSg is MRS containing glucose (positive control).

\section{In vivo safety evaluation}

\section{Animals management and microorganism administration procedures}

$\mathrm{BALB} / \mathrm{c}$ male mice, five to six weeks old, were provided by the Centro de Medicina Comparada, Instituto de Ciencias Veterinarias (ICiVet-Litoral), Faculty of Veterinary Sciences of the National University of Litoral (Esperanza, Santa $\mathrm{Fe}$, Argentina). Prior to the beginning of the study, the project was submitted for evaluation and approved by the National University of Litoral Ethics and Research Committee. Twelve animals were used in the study. Animals were kept for 1 week in the animal facility at the Instituto de Lactología industrial (UNLCONICET) for acclimatization, at $21 \pm 1{ }^{\circ} \mathrm{C}$, in $12 \mathrm{~h} / 12 \mathrm{~h}$ light/dark cycle, with total air renewal rates of 20 volumes/h and ad libitum access to a standard rodent diet (Cooperación, Buenos Aires, Argentina) and sterile tap water.

\section{Bacterial translocation assay}

The mice were divided into 3 groups, each group comprising 4 animals. For 10 consecutive days, mice received $0.3 \mathrm{ml} /$ day of a cell suspension of $L$. rhamnosus 64 (group 1), L. paracasei LP11 (group 2) or a sterile saline solution (control group). The cell suspension contained $10^{7} \mathrm{CFU} / \mathrm{mL}$ of lactobacilli. After 10 days of administration, mice were anesthetized with a ketamine, xylazine and acepromazine cocktail and sacrificed by cervical dislocation.

Liver and spleen were aseptically removed, homogenized in PBS and plated (1 $\mathrm{mL}$ ) on MacConkey agar (Biokar, Beauvais, France) according to Vinderola et al. (2005). Plates were incubated at $37{ }^{\circ} \mathrm{C}$ for $48 \mathrm{~h}$. Results were expressed as positive (presence of bacterial colonies on the plates) or negative (absence of bacterial colonies on the plates, no traslocation).

\section{Statistical analyses}

Statistical analyses were performed in a fully randomized design and two replicates. Data were analyzed by analysis of variance (ANOVA) and Tukey Test using the Statistical Analysis System (SAS, 1995, version 9.1.3). The results were considered statistically significant when $\mathrm{p} \leq 0.05$.

\section{RESULTS AND DISCUSSION}

\section{Lysozyme resistance}

The two evaluated strains presented satisfactory results regarding lysozyme resistance, with $L$. paracasei LP11 displaying higher resistance than $L$. 
rhamnosus $64(\mathrm{p}<0.05)$, as shown in Figure 1. After exposure for 120 minutes to the electrolytic solution at a $100 \mathrm{mg} / \mathrm{l}$ lysozyme dilution simulating in vivo saliva conditions, L. rhamnosus 64 showed a $1.8 \mathrm{log} \mathrm{CFU} / \mathrm{g}$ decrease, while $L$. paracasei LP11 showed a $0.83 \log \mathrm{CFU} / \mathrm{g}$ decrease.

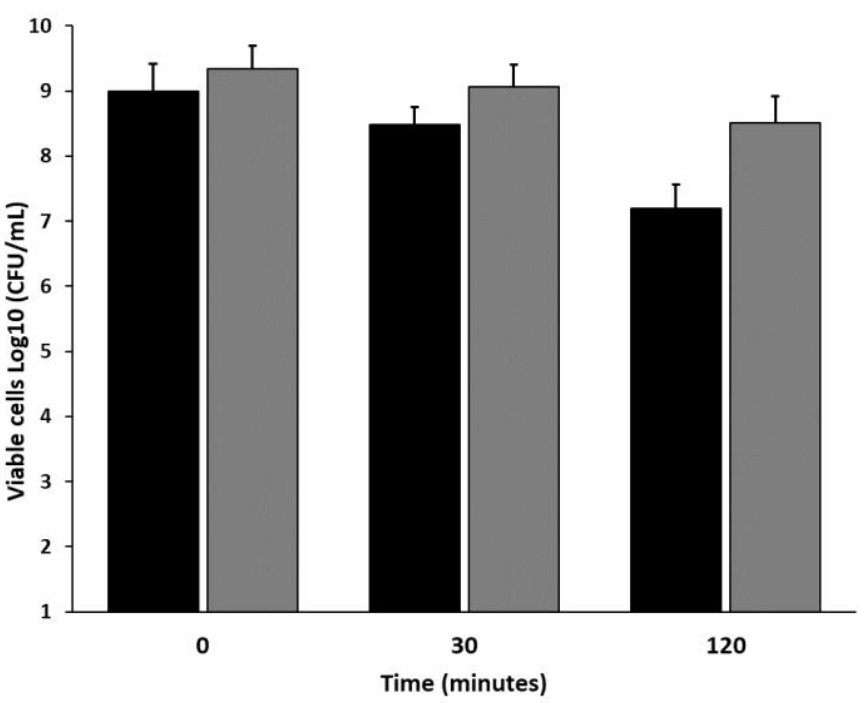

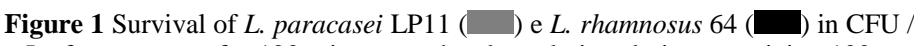
$\mathrm{mL}$ after exposure for 120 minutes to the electrolytic solution containing $100 \mathrm{mg}$ / 1 lysozyme.

Other authors have reported values close to those reported herein. Vizoso Pinto et al. (2006) also evaluated the resistance of L. johnsonii LA1 to lysozyme, exposing the microorganism for 60 minutes to a solution containing lysozyme at a similar concentration and detected a decrease of one logarithmic cycle in relation to the initial microorganism concentration. Zago et al. (2011) evaluated the lysozyme susceptibility of $27 \mathrm{~L}$. plantarum strains isolated from cheeses. The results varied between 3.24 and $99.97 \%$ survival rates after 120 minutes of exposure to the solution containing $100 \mathrm{mg} / \mathrm{l}$ of lysozyme, and 15 strains showed survival above $68 \%$, a result considered satisfactory by the authors. Kõll et al. (2008) evaluated the sensitivity of 22 lactobacilli strains specifically selected as probiotic candidates for oral health performance, and observed after determining the presence of growth inhibition zones that all strains were resistant to lysozyme at concentrations ranging from 0.2 to $10 \mathrm{mg} / \mathrm{ml}$.

Recently, some researchers have suggested the use of probiotics for oral health promotion (Bizzini et al., 2012; Haukioja, 2010), thus encouraging research to develop vehicles for probiotic delivery into the oral cavity. Some of the research published so far (Heinemann, Carvalho, \& Favaro-Trindade, 2013; Saha Tomaro-Duchesneau, Daoud, Tabrizian, \& Prakash, 2013) propose the incorporation of probiotic bacteria in oral disintegration films, allowing the probiotics to comprise the transient microbiota of the buccal mucosa and teeth, permitting protective action against pathogenic microorganisms that promote dental diseases. For this type of study, probiotic sensitivity to lysozyme is crucial, since this enzyme has been shown to be effective in killing several types of Gram-positive bacteria by promoting cell wall rupture and subsequent cell lysis (Kõll et al., 2008).

As observed in several studies, including the one conducted by Zago et al. (2011), lactobacilli sensitivity to lysozyme is a strain-dependent trait. When incorporated into a food product, the sensitivity of the microorganism to lysozyme is not as worrying, since exposure of the probiotic to the enzyme is very short. As seen herein, during the first 30 minutes, the impact of lysozyme on L. paracasei LP11 and L. rhamnosus 64 concentrations was very low. However, it is always prudent to assess such sensitivity, considering that there may be a deleterious summation of buccal secretion and gastrointestinal secretions.

\section{Resistance to simulated gastrointestinal fluids}

In order for the ingested probiotics to reach the intestinal lumen, their main site of action, they must be able to withstand adverse gastrointestinal (GIT). In order to have a physiological impact, it is desirable that probiotics reach the GIT in concentrations higher than $7 \log$ CFU/g (Gill \& Rutherfurd, 2001; Ya et al., 2008).

After exposure to gastrointestinal fluids, the behavior of L. paracasei LP11 and L. rhamnosus 64 was observed after 120 minutes exposure to simulated gastric fluid ( $\mathrm{p}<0.05$ ). While L. rhamnosus 64 showed a $1.31 \log C F U / g$ decrease, the decrease of L. paracasei LP11 concentrations reached $3.37 \mathrm{log}$ CFU/g (Fig. 2). However, the behavior of both strains in relation to exposure to simulated intestinal fluids for 90 minutes was not significantly different $(p>0.05)$, with no significant concentration decreases. After gastrointestinal fluid exposure, data indicated that L. rhamnosus 64 presented a final concentration of $6.05 \log \mathrm{CFU} / \mathrm{g}$, while $L$. paracasei LP11 presented a final concentration of $3.92 \log \mathrm{CFU} / \mathrm{g}$.

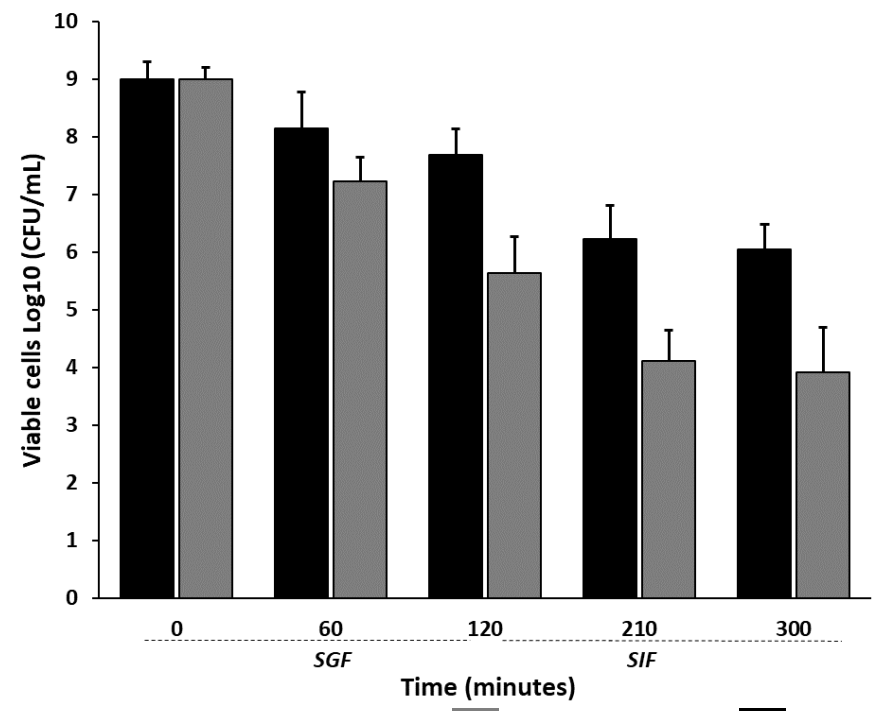

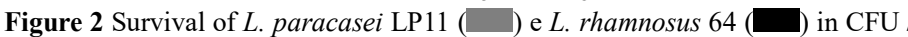
$\mathrm{mL}$ after $300 \mathrm{~min}$ exposure to simulated gastrointestinal fluids (SGF), with 120 minutes of exposure in simulated gastric fluid and 180 minutes of exposure in simulated intestinal fluids (SIF).

Significant decreases in the concentrations of viable lactobacilli cells exposed to gastrointestinal fluids have been reported by several authors. Ilha, da Silva, Lorenz, de Oliveira Rocha, \& Sant'Anna (2015) characterizing L. paracasei, reported a $4.25 \log \mathrm{CFU} / \mathrm{mL}$ decrease after exposure to $\mathrm{pH} 2.0$ for 3 hours. Ding \& Shah (2007) evaluated the resistance of $L$. rhamnosus and $L$. paracasei at $\mathrm{pH}$ 2.0 for 2 hours and reported a decrease of 6.69 and $6.61 \log$ CFU/mL for each microorganism, respectively. Pimentel-González, Campos-Montiel, LobatoCalleros, Pedroza-Islas, \& Vernon-Carter (2009) reported that L. rhamnosus when exposed under simulated gastric conditions at $\mathrm{pH} 2.3$ for 2 hours presented a $1.87 \log \mathrm{CFU} / \mathrm{mL}$ decrease in relation to initial concentrations.

Some probiotic-candidate microorganisms may present high sensitivity to gastrointestinal fluids, but promising results in other characterization tests or when included in a food matrix. One way to overcome this high sensitivity is the use of microencapsulation technology, which has demonstrated satisfactory efficiency in increasing survival against GIT conditions (Bosnea et al., 2014 Cook et al., 2012; de Vos et al., 2010; Pedroso et al., 2012). Several microencapsulation techniques have been successfully applied in the protection of probiotic cells, with emphasis on spray chilling (Okuro, de Matos, \& FavaroTrindade, 2013; Pedroso, Dogenski, Thomazini, Heinemann, \& Favaro-Trindade, 2013) and complex coacervation (Bosnea et al., 2014; Oliveira et al., 2007). In this context, although L. paracasei LP11 and L. rhamnosus 64 showed high sensitivity to gastrointestinal fluids, the use of the microencapsulation technology could be advantageous, depending on the results of the other probiotic potential characterization tests.

\section{Hydrophobicity}

Significant attention has been paid to cell wall hydrophobicity profiles in the characterization of microorganisms with probiotic potential. Although hydrophobicity is not the only factor related to the complex adhesion process of microorganisms to the intestinal epithelium, some authors state that the initial stage of this fixation is mediated by physico-chemical interactions that include hydrophobicity and chemical charges (Barbosa, Silva, Martins, \& Nicoli, 2005; Pelletier et al., 1997). It is believed that the higher the hydrophobicity of the surface of the microorganism, the greater its adhesion capacity (Kos et al., 2003; Rosenberg, Gutnick, \& Rosenberg, 1980). Although some studies claim that lactobacilli generally present a hydrophobic cell surface (García-Cayuela et al., 2014), it is possible to find studies with varied hydrophobicity values, including values below 10\% (Dhewa, Bajpai, Saxena, Pant, \& Mishra, 2010; Zago et al., 2011) and above 90\% (Mangoni et al., 2011; Van Coillie et al., 2007).

In the present study L. rhamnosus 64 presented $19.19 \%$ hydrophobicity, while $L$. paracasei LP11 presented $8.47 \%$, within the range reported in the literature Other studies that have also evaluated L. rhamnosus and L. paracasei strains support the claim that cell surface hydrophobicity profile, as well as several other characteristics expected for probiotic microorganisms, is strain-dependent. Pelletier et al. (1997) cites values between 8.3 and $9.6 \%$ and 8.7 and $26.5 \%$ hydrophobicity for L. paracasei and L. Rhamnosus strains, respectively, while $\mathrm{Xu}$, Jeong, Lee, \& Ahn (2009) reported hydrophobicity values close to 25 and $46 \%$ for $L$. paracasei and L. rhamnosus GG, respectively. Polak-Berecka, Waśko, Paduch, Skrzypek, \& Sroka-Bartnicka (2014) also used hexadecane as solvent to 
evaluate the hydrophobicity of L. rhamnosus and reported values between 11 and $16 \%$.

It is important to note that, although it is desirable for a probiotic to have a hydrophobic outer surface, so that it is able to withstand the effects of intestinal peristalsis of the intestinal fluid stream and not be eliminated, this should not be a limiting feature in probiotic selection, since, as observed by Santos et al. (2016), probiotics with remarkable positive functional characteristics and low hydrophobicity are also available.

\section{Antibiotic susceptibility analysis}

The results of the antibiotic susceptibility analysis of the two evaluated lactobacilli strains are summarized in Table 1. L. rhamnosus 64 showed sensitivity to five of the eight evaluated antibiotics, presenting moderate sensitivity to penicillin and tetracycline and resistance to erythromycin. On the other hand, L. paracasei LP11 showed sensitivity to penicillin and moderate sensitivity to erythromycin and tetracycline. Both strains were resistant to vancomycin, which corroborates several studies, both recent (Aazami et al, 2014; Haghshenas et al., 2015; Santos et al., 2016) and otherwise (HamiltonMiller \& Shah, 1998). In summary, the resistance profile of L. rhamnosus 64 and L. paracasei LP11 to the evaluated antibiotics did not differ compared to reports published in the literature (Gueimonde, Sánchez, G. de los Reyes-Gavilán, \& Margolles, 2013; Kõll et al., 2008; Santos et al., 2016; M. Sharma \& Devi, 2014; Vizoso Pinto et al., 2006).

Table 1 Antibiotic resistance profile of L. rhamnosus 64 and L. paracasei LP11

\begin{tabular}{|c|c|c|c|c|c|c|c|c|}
\hline \multirow[t]{2}{*}{ Strains } & \multicolumn{8}{|c|}{ Antibiotics } \\
\hline & Cefe & Cefo & Ceft & Eri & $\mathrm{Neo}$ & Pen & Tet & Van \\
\hline $\begin{array}{l}\text { L. rhamnosus } 64 \\
\text { L. paracasei LP11 }\end{array}$ & $\mathrm{S}$ & $\mathrm{S}$ & $\mathrm{S}$ & $\mathrm{R}$ & S & MS & MS & $\mathrm{R}$ \\
\hline
\end{tabular}

penicillin (Pen) $(10 \mu \mathrm{g})$, tetracycline (Tet) $(30 \mu \mathrm{g})$ and vancomycin (Van) $(30 \mu \mathrm{g})$. S: sensitive, MS: moderately sensitive, R: resistant.

Probiotic resistance to antibacterial drugs does not necessarily motivate concerns; on the contrary, the use of resistant probiotics may be useful for the restoration of the intestinal microbiota after treatment with antibiotics (Gueimonde et al., 2013). However, a problem arises when the resistance is transferable, allowing pathogenic microorganisms to acquire resistance through bacteria used as probiotics (Bernardeau, Vernoux, Henri-Dubernet, \& Guéguen, 2008; P. Sharma, Tomar, Goswami, Sangwan, \& Singh, 2014). The resistance of lactobacilli strains to erythromycin and vancomycin detected herein has been reported in the literature as an intrinsic resistance without the risk of horizontal transfer (Ammor, Belén Flórez, \& Mayo, 2007; Gad, Abdel-Hamid, \& Farag, 2014; Rabia \& Shah, 2011).

\section{In vitro antagonism}

L. paracasei LP11 and L. rhamnosus 64 were able to promote an antagonistic effect against the four evaluated pathogens (Escherichia coli V517, Salmonella enteritidis OMS-Ca, Staphylococcus aureus 76 and Listeria monocytogenes ATCC 15313). A pathogen growth inhibition zone greater than $6 \mathrm{~mm}$ was observed in all spots containing active lactobacilli cells (Table 2). No positive inhibition results regarding antagonist activity of the supernatants obtained from the growth of the lactobacillus strains neutralized with $5 \mathrm{M} \mathrm{NaOH}$ and boiled for 5 minutes was detected, indicating that the inhibition observed by active cells was not due to the production of thermoresistant bacteriocins. Similar reports have been published by other authors evaluating lactobacilli strains (Maragkoudakis et al., 2006; Poppi et al., 2015; Vizoso Pinto et al., 2006). Those studies suggest that the antagonistic effect in this case is possibly due to the production of organic acids. This statement, however, is not unanimous in the literature. Santos et al., (2016), for example, reported that neutralized supernatants from lactobacillus isolates isolated from cocoa fermentation were able to inhibit $E$. coli ATCC 25922 growth, noting that $L$. plantarum supernatants also inhibited S. enterica var. Typhimurium ATTCC 14028 and Shiguella flexi ATTCC11060.

Table 2 Evaluation of in vitro antagonism capacity of L. rhamnosus 64 and L. paracasei LP11

\begin{tabular}{|c|c|c|c|c|}
\hline \multirow[t]{2}{*}{ Strains } & \multicolumn{4}{|c|}{ Pathogens } \\
\hline & $E C$ & $S E$ & $A S$ & $L M$ \\
\hline L. rhamnosus 64 & + & + & + & + \\
\hline L. paracasei LP11 & + & + & + & + \\
\hline
\end{tabular}

Prebiotic use

Considering that prebiotics are non-digestible food ingredients capable of selectively stimulating probiotic growth (Gibson \& Roberfroid, 1995), the evaluation of the probiotic microorganism capacity to use prebiotics is indispensable, especially when their use in symbiotic products is envisaged Considering that recent research has demonstrated that the ability to use prebiotics is a strain-dependent trait (Mandadzhieva, Ignatova-Ivanova, Kambarev, Iliev, \& Ivanova, 2011; Zago et al., 2011), the two lactobacilli strains studied herein were evaluated for their capacity to use four prebiotics: inulin, polydextrose, P95 rafthiosis and lactulose. As displayed in Figure 3, L. paracase LP11 showed high growth in the presence of inulin and fructooligosaccharides, with cell growth rates of $75 \%$ and $86 \%$, respectively, in relation to the control. However, this strain presented growth rates lower than $35 \%$ in the presence of polydextrose or lactulose. L. rhamnosus 64 , on the other hand, presented high growth only in the presence of lactulose, of $91 \%$ in relation to the control, and cellular growth rate of less than $40 \%$ in the presence of the other evaluated prebiotics. When the growth performance of the two strains was evaluated in the presence of each prebiotic, inverse behaviors $(p<0.05)$ were observed, except for polydextrose, which did not result in any growth difference between the two strains $(\mathrm{p}>0.05)$.

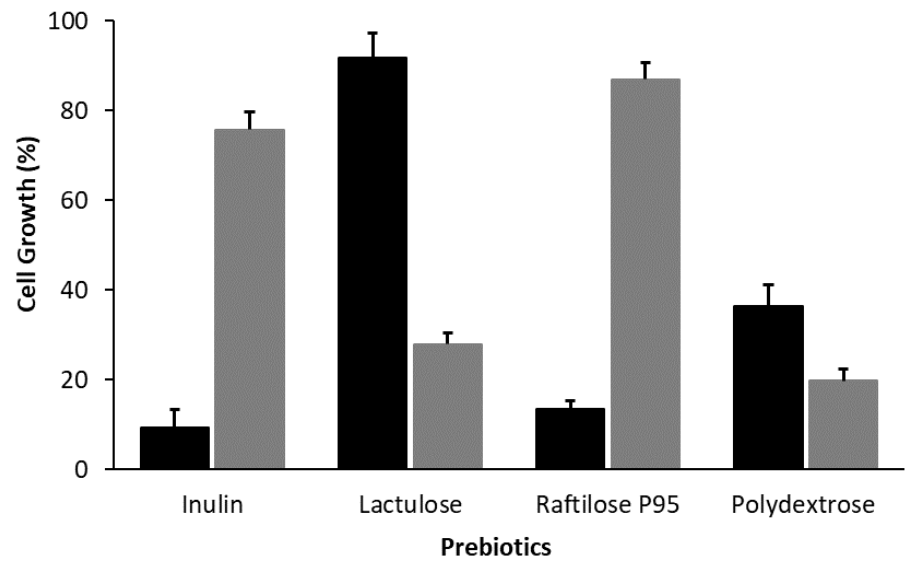

Figure 3 Use of inulin, lactulose, P95 rafthiosis and polydextrose by L. paracasei LP11 ( ) and L. rhamnosus 64 ( ) during growth. The Prebiotic Utilization Capacity (CUP) values were expressed as percentage of cell growth in relation to glucose (100\% of use), used as control after 24 hours of incubation. 
Lactulose that, in this study, promoted a high growth rate for L. rhamnosus 64 and low for $L$. paracasei LP11 was also the target of a study performed by Zago et al. (2011) regarding its use by $27 \mathrm{~L}$. plantarum strains isolated from cheese The authors reported that lactulose, among seven evaluated prebiotics, provided the highest cell growth rate for all the investigated strains, with values close to $100 \%$ in relation to the control. Kunová, Rada, Lisova, Ročkova, \& Vlková (2011) also reported successful results regarding the use of lactulose by several lactobacilli species, although inulin promoted the highest growth rates. Watson $e$ al., (2013) observed satisfactory growth rates for 21 lactobacillus species when using lactulose, noting that the same strains were not able to use inulin and polydextrose.

The studies available in the literature present mixed results, reinforcing the assertion that probiotic use of prebiotics is a strain-dependent characteristic (Tropcheva et al., 2013), and prevent any kind of generalization. However, a frequently reported behavior is the low capacity or inability of lactobacilli to use polydextrose (Mäkeläinen, Saarinen, Stowell, Rautonen, \& Ouwehand, 2010; Watson et al., 2013; Zago et al., 2011), a fact corroborated by the findings reported herein, for both L. rhamnosus 64 and L. paracasei LP11. Polydextrose presents a complex structure, and is difficult and slow to degrade, requiring the performance of several intestinal microbiota microorganisms to promote at least partial molecular degradation (Röytiö \& Ouwehand, 2014). Although results from in vitro tests with isolated probiotic microorganisms are not successful in terms of the ability to use polydextrose, it is important to note that some clinical studies have confirmed the ability of this prebiotic to beneficially modulate intestinal microbiota (Costabile et al., 2012; Hooda et al., 2012; Jie et al., 2000; Lamichhane et al., 2014).

Inulin and fructooligosaccharides are among the most commonly used prebiotic ingredients for the development of symbiotic foods (Buriti, Cardarelli, Filisetti, \& Saad, 2007; Fornelli et al., 2014; Moayednia, 2014; Paula K Okuro, Thomazini, Balieiro, Liberal, \& Fávaro-Trindade, 2013; Paz, Oliveira, Kairuz, \& Ramón, 2014), although the ability of these probiotics to use these probiotic microorganisms is not always tested. With recognized bifidogenic effects (Búrigo, Fagundes, Trindade, \& Vasconcelos, 2007; Shoaib et al., 2016), inulin and fructooligosaccharides have also demonstrated positive effects for lactobacilli. Souza Oliveira, Perego, de Oliveira e Converti (2012) reported satisfactory results regarding the effect of inulin on growth and metabolism of $L$. rhamnosus in co-culture with Streptococcus thermophilus. Makras, Van Acker e De Vuyst (2005) observed that Lactobacillus paracasei subsp. paracasei 8700: 2 isolated from breast milk was able to use inulin and fructooligosaccharides. On the other hand, in the studies conducted by Adebola, Corcoran and Morgan (2014), L. acidophilus NCTC 1723, L. delbrueckii ssp. bulgaricus NCTC 12712 and L. brevis NCIMB 11973 were not able to use inulin as a carbon source.

It is pertinent to point out that the fact that a prebiotic does not stimulate the growth of the probiotic present in the symbiotic food does not mean that its activity is useless, since other strains belonging to the intestinal microbiota can be stimulated, promoting host benefits. However, it is strongly expected that the prebiotic should display the ability to stimulate the growth of the accompanying probiotic in a symbiotic food.

\section{In vivo safety evaluation}

No bacterial translocation to liver or spleen was observed for the dose of $L$ paracasei LP11 and L. rhamnosus 64 assessed, suggesting that these microorganisms did not alter the integrity of the intestinal epithelium or the balance of the resident microbiota.

The translocation of bacteria from the enteric microbiota to extraintestinal sites due to microorganism administration is one of the most worrisome adverse effects of this practice. Considered a probiotic toxicity factor, bacterial translocation may be related to the pathogenesis process of opportunistic strain (Zago et al., 2011). Several authors have investigated the translocation possibility of probiotic-candidate lactobacilli strains. Medici, Vinderola, \& Perdigón (2004) reported negative results for translocation when evaluating $L$. acidophilus and $L$. paracasei isolated from cheese. Similar results were reported by Zago et al (2011) when evaluating the administration of $L$. plantarum strains derived from cheeses.

In 2005, a study carried out by Vinderola et al. (2005) suggested that the possibility of bacterial translocation could be related to the dosage. When studying the immunomodulatory effect of kefir in mice, the authors verified the occurrence of bacterial translocation to spleen and liver when daily doses of kefir diluted at $1 / 10$ and $1 / 50$ ratios were administered. However, when the kefir was was administered at $1 / 100$ and $1 / 200$ ratios, bacterial translocation was negative Gregoret, Perezlindo, Vinderola, Reinheimer, \& Binetti (2013), who administered doses higher than the one evaluated herein, did not verify bacterial translocation at daily doses of $2 \times 10^{8} \mathrm{CFU}$ for up to 7 days for L. paracasei, L. rhamnosus and $L$. gasseri isolated from newborn feces. As the risk of bacterial translocation may correlate with dosage, it is important to perform oral ingestion safety tests as a preliminary step in food development.

\section{CONCLUSIONS}

The in vitro evaluation performed herein revealed that the two lactobacilli strains presented satisfactory results in most of the conducted tests, demonstrating potential for use as probiotic microorganisms in functional foods. The analysis of resistance to gastrointestinal conditions was the only feature that fell short of the desired. However, such resistance can be improved by microencapsulation technology, which has shown promising results. In the safety test performed in vivo, the ingestion of both strains was shown to be safe at the dosage administered in an animal model. Once resistance to gastrointestinal conditions has been improved, the microorganisms must undergo in vivo tests in order to determine their possible functionalities in the organism, to be subsequently applied in a food matrix.

Acknowledgments: The authors thank the Coordenação de Aperfeiçoamento de Pessoal de Nível Superior (CAPES) for the scholarships that were granted to Fernando Eustáquio de Matos Jr. We also thank the financial support provided by Ministerio de Ciencia y Tecnologia de La Nación (MINCyT) and Coordenação de Aperfeiçoamento de Pessoal de Nível Superior (CAPES), by project CAPES/MINCyT 23038.0011232/2014-67. This study was partially supported by the projects "Desarrollo de cultivos probióticos nacionales a partir de cepas autóctonas de lactobacilos y bifidobacterias", project CAI+D Call 2011, code 501 20110100136 LI, period 2013-2016, "Cultivos microbianos autóctonos para la producción de alimentos funcionales para humanos y animales utilizando secado spray", project PICT-2013-0260, ANPCyT Resolution N ${ }^{\circ}$ 214/14. The authors also thank CNPq for financial support (Process 462493/2014-8) and for the productivity grant for C.S. Fávaro Trindade (306708/2015-9)

\section{REFERENCES}

Aazami, N., Salehi Jouzani, G., Khodaei, Z., Meimandipour, A., Safari, M., \& Goudarzvand, M. (2014). Characterization of some potentially probiotic Lactobacillus strains isolated from Iranian native chickens. The Journal of General and Applied Microbiology, 60(6), 215-221. https://doi.org/10.2323/jgam.60.215

Adebola, O. O., Corcoran, O., \& Morgan, W. A. (2014). Synbiotics: the impact of potential prebiotics inulin, lactulose and lactobionic acid on the survival and growth of lactobacilli probiotics. Journal of Functional Foods, 10, 75-84. https://doi.org/http://dx.doi.org/10.1016/j.jff.2014.05.010

Ammor, M. S., Belén Flórez, A., \& Mayo, B. (2007). Antibiotic resistance in non-enterococcal lactic acid bacteria and bifidobacteria. Food Microbiology 24(6), 559-570. https://doi.org/http://dx.doi.org/10.1016/j.fm.2006.11.001

Ashraf, R., \& Shah, N. P. (2014). Immune System Stimulation by Probiotic Microorganisms. Critical Reviews in Food Science and Nutrition, 54(7), 938956. https://doi.org/10.1080/10408398.2011.619671

BARBOSA, F. H. F. ., SILVA, A. M. da; MARTINS, F. S. dos; \& NICOLI, J R. (2005). Perfil de hidrofobicidade da superfície celular de Bifidobacterium lactis Bb12 e Bifidobacterium longum Bb46 em função do meio de cultura Revista de Biologia e Ciências Da Terra, 5(2), 1-5.

Bauer, A. W., Kirby, W. M., Sherris, J. C., \& Turck, M. (1966). Antibiotic susceptibility testing by a standardized single disk method. American Journal of Clinical Pathology, 45(4), 493-496. https://doi.org/10.1016/S03054179(78)80006-0

Begum, P., Madhavi, G., Rajagopal, S., Viswanath, B., Razak, M., \& Venkataratnamma, V. (2017). Probiotics as Functional Foods: Potential Effects on Human Health and its Impact on Neurological Diseases. International Journa of Nutrition, Pharmacology, Neurological Diseases, 7(2), 23-33. https://doi.org/10.4103/ijnpnd.ijnpnd_90_16

Bernardeau, M., Vernoux, J. P., Henri-Dubernet, S., \& Guéguen, M. (2008) Safety assessment of dairy microorganisms: The Lactobacillus genus International Journal of Food Microbiology, 126(3), 278-285. https://doi.org/http://dx.doi.org/10.1016/j.ijfoodmicro.2007.08.015

Bizzini, B., Pizzo, G., Scapagnini, G., \& Vasto, D. N. and S. (2012). Probiotics and Oral Health. Current Pharmaceutical Design. https://doi.org/http://dx.doi.org/10.2174/138161212803307473

Bosnea, L. a., Moschakis, T., \& Biliaderis, C. G. (2014). Complex Coacervation as a Novel Microencapsulation Technique to Improve Viability of Probiotics Under Different Stresses. Food and Bioprocess Technology, 7(10), 2767-2781. https://doi.org/10.1007/s11947-014-1317-7

Búrigo, T., Fagundes, R. L. M., Trindade, E. B. S. de M., \& Vasconcelos, H. C. F. F. (2007). Efeito bifidogênico do frutooligossacarídeo na microbiota intestinal de pacientes com neoplasia hematológica . Revista de Nutrição. 20(5), 491-497. https://dx.doi.org/10.1590/S1415-52732007000500005

Buriti, F. C. A., Cardarelli, H. R., Filisetti, T. M. C. C., \& Saad, S. M. I. (2007) Synbiotic potential of fresh cream cheese supplemented with inulin and Lactobacillus paracasei in co-culture with Streptococcus thermophilus. Food Chemistry, 104(4), 1605-1610. https://doi.org/10.1016/j.foodchem.2007.03.001 Castillo, N. A., de Moreno de LeBlanc, A., Galdeano, C. M., \& Perdigón, G. (2012). Probiotics: An alternative strategy for combating salmonellosis. Immune 
mechanisms involved. Food Research International, 45(2), 831-841. https://doi.org/10.1016/j.foodres.2011.04.031

Champagne, C. P., Gardner, N. J., \& Roy, D. (2005). Challenges in the addition of probiotic cultures to foods. Critical Reviews in Food Science and Nutrition, 45(1), 61-84. https://doi.org/10.1080/10408690590900144

Cook, M. T., Tzortzis, G., Charalampopoulos, D., \& Khutoryanskiy, V. V. (2012). Microencapsulation of probiotics for gastrointestinal delivery. Journal of Controlled Release: Official Journal of the Controlled Release Society, 162(1), 56-67. https://doi.org/10.1016/j.jconrel.2012.06.003

Costabile, A., Fava, F., Röytiö, H., Forssten, S. D., Olli, K., Klievink, J., Walton, G. E. (2012). Impact of polydextrose on the faecal microbiota: a double-blind, crossover, placebo-controlled feeding study in healthy human subjects. British Journal of Nutrition, 108(03), 471-481. https://doi.org/10.1017/S0007114511005782

de Souza Oliveira, R. P., Perego, P., de Oliveira, M. N., \& Converti, A. (2012). Effect of inulin on the growth and metabolism of a probiotic strain of Lactobacillus rhamnosus in co-culture with Streptococcus thermophilus. $L W T$ Food Science and Technology, 47(2), 358-363. https://doi.org/http://dx.doi.org/10.1016/j.lwt.2012.01.031

de Vos, P., Faas, M. M., Spasojevic, M., \& Sikkema, J. (2010). Encapsulation for preservation of functionality and targeted delivery of bioactive food components. $\begin{array}{llll}\text { International Dairy } & \text { Journal, 292-302. }\end{array}$ https://doi.org/10.1016/j.idairyj.2009.11.008

Dhewa, T., Bajpai, V., Saxena, R. K., Pant, S., \& Mishra, V. (2010). Selection of Lactobacillus strains as potential probiotics on basis of in vitro attributes. International Journal of Probiotics and Prebiotics, 5(1), 45-51.

Dias, D. R., Botrel, D. A., Fernandes, R. V. D. B., \& Borges, S. V. (2017) Encapsulation as a tool for bioprocessing of functional foods. Current Opinion in Food Science, 13(Supplement $\quad$ C), 31-37. https://doi.org/https://doi.org/10.1016/j.cofs.2017.02.001

Ding, W. K., \& Shah, N. P. (2007). Acid, Bile, and Heat Tolerance of Free and Microencapsulated Probiotic Bacteria. Journal of Food Science, 72(9), M446M450. https://doi.org/10.1111/j.1750-3841.2007.00565.x

Duary, R. K., Rajput, Y. S., Batish, V. K., \& Grover, S. (2011). Assessing the adhesion of putative indigenous probiotic lactobacilli to human colonic epithelia cells. The Indian Journal of Medical Research, 134(5), 664-671. https://doi.org/10.4103/0971-5916.90992

Food and Agriculture Organization of the United Nations / World Health Organization. (2002). Guidelines for the evaluation of probiotics in food. Joint FAO/WHO Working Group Report. Ontario.

Fornelli, A. R., Bandiera, N. S., Costa, M. de R., Souza, C. H. B., Santana, E. H. W., Sivieri, K., \& Aragon-Alegro, L. C. (2014). Effect of inulin and oligofructose on the physicochemical, microbiological and sensory characteristics of symbiotic dairy beverages. Semina: Ciências Agrárias, 35(6), 3099-3111. https://doi.org/dx.doi.org/10.5433/1679-0359.2014v35n6p3099

Gad, G. F. M., Abdel-Hamid, A. M., \& Farag, Z. S. H. (2014). Antibiotic resistance in lactic acid bacteria isolated from some pharmaceutical and dairy products. Brazilian Journal of Microbiology, 45(1), 25-33. http://dx.doi.org/10.1590/S1517-83822014000100005.

García-Cayuela, T., Korany, A. M., Bustos, I., P. Gómez de Cadiñanos, L. Requena, T., Peláez, C., \& Martínez-Cuesta, M. C. (2014). Adhesion abilities of dairy Lactobacillus plantarum strains showing an aggregation phenotype. Food Research International, 57, 44-50. https://doi.org/10.1016/j.foodres.2014.01.010 Gbassi, G. K., Vandamme, T., Ennahar, S., \& Marchioni, E. (2009) Microencapsulation of Lactobacillus plantarum spp in an alginate matrix coated with whey proteins. International Journal of Food Microbiology, 129(1), 103105. https://doi.org/10.1016/j.ijfoodmicro.2008.11.012

Gibson, G. R. (2004). Fibre and effects on probiotics (the prebiotic concept). Clinical Nutrition $\quad$ Supplements, $1(2), \quad 25-31$. https://doi.org/https://doi.org/10.1016/j.clnu.2004.09.005

Gibson, G. R., \& Roberfroid, M. B. (1995). Dietary Modulation of the Human Colonic Microbiota: Introducing the Concept of Prebiotics. The Journal of Nutrition, 125(6), 1401-1412.

Gill, H. S., \& Rutherfurd, K. J. (2001). Viability and dose-response studies on the effects of the immunoenhancing lactic acid bacterium Lactobacillus rhamnosus in mice. British Journal of Nutrition, 86(2), 285-289. https://doi.org/DOI: 10.1079/BJN2001402

Granato, D., Branco, G. F., Cruz, A. G., Faria, J. de A. F., \& Shah, N. P. (2010). Probiotic Dairy Products as Functional Foods. Comprehensive Reviews in Food Science and Food Safety, 9(5), 455-470. https://doi.org/10.1111/j.15414337.2010.00120.x

Gregoret, V., Perezlindo, M. J., Vinderola, G., Reinheimer, J., \& Binetti, A (2013). A comprehensive approach to determine the probiotic potential of human-derived Lactobacillus for industrial use. Food Microbiology, 34(1), 1928. https://doi.org/https://doi.org/10.1016/j.fm.2012.11.004

Gueimonde, M., Sánchez, B., G. de los Reyes-Gavilán, C., \& Margolles, A. (2013). Antibiotic resistance in probiotic bacteria. Frontiers in Microbiology, 4 202. https://doi.org/10.3389/fmicb.2013.00202
Gul, K., Singh, A. K., \& Jabeen, R. (2016). Nutraceuticals and Functional Foods: The Foods for the Future World. Critical Reviews in Food Science and Nutrition, 56(16), 2617-2627. https://doi.org/10.1080/10408398.2014.903384

Haghshenas, B., Nami, Y., Haghshenas, M., Abdullah, N., Rosli, R., Radiah, D., \& Yari Khosroushahi, A. (2015). Bioactivity characterization of Lactobacillus strains isolated from dairy products. MicrobiologyOpen, 4(5), 803-813. https://doi.org/10.1002/mbo3.280

Hamilton-Miller, \& Shah. (1998). Vancomycin susceptibility as an aid to the identification of lactobacilli. Letters in Applied Microbiology, 26(2), 153-154. https://doi.org/10.1046/j.1472-765X.1998.00297.x

Haukioja, A. (2010). Probiotics and Oral Health. European Journal of Dentistry, 4(3), 348-355.

Havenaar, R., Brink, B. Ten, \& Huis In 't Veld, J. H. J. (1992). Selection of strains for probiotic use. In Probiotics: The scientific basis (pp. 209-224) Dordrecht: Springer Netherlands. https://doi.org/10.1007/978-94-011-2364-8 9

Hegarty, J. W., Guinane, C. M., Ross, R. P., Hill, C., \& Cotter, P. D. (2016). Bacteriocin production: a relatively unharnessed probiotic trait? F1000Research, 5, 2587. https://doi.org/10.12688/f1000research.9615.1

Heinemann, R. J. B., Carvalho, R. A., \& Favaro-Trindade, C. S. (2013). Orally disintegrating film (ODF) for delivery of probiotics in the oral cavity Development of a novel product for oral health. Innovative Food Science \& Emerging Technologies, 19,

https://doi.org/http://dx.doi.org/10.1016/j.ifset.2013.04.009

Hooda, S., Boler Vester, B. M., Serao Rossoni, M. C., Brulc, J. M., Staeger, M. A., Boileau, T. W., Swanson, K. S. (2012). 454 Pyrosequencing Reveals a Shift in Fecal Microbiota of Healthy Adult Men Consuming Polydextrose or Soluble Corn Fiber. The Journal of Nutrition . https://doi.org/10.3945/jn.112.158766

Ilha, E. C., da Silva, T., Lorenz, J. G., de Oliveira Rocha, G., \& Sant'Anna, E. S (2015). Lactobacillus paracasei isolated from grape sourdough: acid, bile, salt, and heat tolerance after spray drying with skim milk and cheese whey. European Food Research and Technology, 240(5), 977-984. https://doi.org/10.1007/s00217-014-2402-x

Islam, M. A. (2010). Microencapsulation of Live Probiotic Bacteria. Journal of $\begin{array}{lll}\text { Microbiology and Biotechnology, 20(10), 1367-1377. } & \end{array}$ https://doi.org/10.4014/jmb.1003.03020

Jie, Z., Bang-yao, L., Ming-jie, X., Hai-wei, L., Zu-kang, Z., Ting-song, W., \& Craig, S. A. S. (2000). Studies on the effects of polydextrose intake on physiologic functions in Chinese people. The American Journal of Clinical Nutrition , 72(6), 1503-1509.

Kanmani, P., Satish Kumar, R., Yuvaraj, N., Paari, K. a, Pattukumar, V., \& Arul, V. (2013). Probiotics and its functionally valuable products-a review. Critical Reviews in Food Science and Nutrition, 53(6), 641-58. https://doi.org/10.1080/10408398.2011.553752

Kõll, P., Mändar, R., Marcotte, H., Leibur, E., Mikelsaar, M., \& Hammarström, L. (2008). Characterization of oral lactobacilli as potential probiotics for oral health. Oral Microbiology and Immunology, 23(2), 139-147. https://doi.org/10.1111/j.1399-302X.2007.00402.x

Kos, B., Šušković, J., Vuković, S., Šimpraga, M., Frece, J., \& Matošić, S. (2003) Adhesion and aggregation ability of probiotic strain Lactobacillus acidophilus M92. Journal of Applied Microbiology, 94(6), 981-987. https://doi.org/10.1046/j.1365-2672.2003.01915.x

Kunová, G., Rada, V., Lisova, I., Ročkova, Š., \& Vlková, E. (2011). In vitro fermentability of prebiotic oligosaccharides by lactobacilli. Czech Journal of Foof Science, 29 (Special Issue), S49-S54

Lähteenmäki, L. (2013). Claiming health in food products. Food Quality and Preference, $27(2)$,

196-201.

https://doi.org/https://doi.org/10.1016/j.foodqual.2012.03.006

Lamichhane, S., Yde, C. C., Forssten, S., Ouwehand, A. C., Saarinen, M., Jensen, H. M., ... Bertram, H. C. (2014). Impact of Dietary Polydextrose Fiber on the Human Gut Metabolome. Journal of Agricultural and Food Chemistry, 62(40), 9944-9951. https://doi.org/10.1021/jf5031218

LeBlanc, J. G., Laiño, J. E., del Valle, M. J., Vannini, V., van Sinderen, D. Taranto, M. P., Sesma, F. (2011). B-Group vitamin production by lactic acid bacteria - current knowledge and potential applications. Journal of Applied Microbiology, 111(6), 1297-1309. https://doi.org/10.1111/j.13652672.2011.05157.x

Mäkeläinen, H., Saarinen, M., Stowell, J., Rautonen, N., \& Ouwehand, A. (2010). Xylo-oligosaccharides and lactitol promote the growth of Bifidobacterium lactis and Lactobacillus species in pure cultures. Beneficial Microbes, 1(2), 139-148. https://doi.org/10.3920/BM2009.0029

Makras, L., Van Acker, G., \& De Vuyst, L. (2005). Lactobacillus paracasei subsp. paracasei 8700:2 Degrades Inulin-Type Fructans Exhibiting Different Degrees of Polymerization. Applied and Environmental Microbiology, 71(11), 6531-6537. https://doi.org/10.1128/AEM.71.11.6531-6537.2005

Mandadzhieva, T., Ignatova-Ivanova, T., Kambarev, S., Iliev, I., \& Ivanova, I. (2011). Utilization of Different Prebiotics by Lactobacillus Spp. and Lactococcus Spp. Biotechnology \& Biotechnological Equipment, 25(sup1), 117-120. https://doi.org/10.5504/BBEQ.2011.0132

Mangoni, J., Pozza, M. S. dos S., Sabedot, M. A., Pozza, P. C., Almeida, S. de, \& Heinzen, E. L. (2011). Potencial probiótico de lactobacilos de origem suína . Acta 
Scientiarum.

Animal

http://dx.doi.org/10.4025/actascianimsci.v33i3.9826

Maragkoudakis, P. A., Zoumpopoulou, G., Miaris, C., Kalantzopoulos, G., Pot, B., \& Tsakalidou, E. (2006). Probiotic potential of Lactobacillus strains isolated from dairy products. International Dairy Journal, 16(3), 189-199. https://doi.org/http://dx.doi.org/10.1016/j.idairyj.2005.02.009

Mattila-Sandholm, T., Myllärinen, P., Crittenden, R., Mogensen, G., Fondén, R., \& Saarela, M. (2002). Technological challenges for future Probiotic foods. In International Dairy Journal (Vol. 12, pp. 173-182). https://doi.org/10.1016/S0958-6946(01)00099-1

Medici, M., Vinderola, C. G., \& Perdigón, G. (2004). Gut mucosal immunomodulation by probiotic fresh cheese. International Dairy Journal, 14(7), 611-618. https://doi.org/https://doi.org/10.1016/j.idairyj.2003.10.011

Moayednia, N. (2014). Quality Evaluation of New Developed Symbiotic Yogurt over the Storage at Refrigerator. Journal of Food Biosciences and Technology, 04(1), 57-64.

Niamah, A. K. (2010). Production of Pediocin like bacteriocin From a Local Isolate of Pediococcus acidilactici and Using it as Foods preservative. University of

Basrah

https://doi org/https://doi oro/10.13140/RG 2231314.35529

Okuro, P. K., de Matos, F. E., \& Favaro-Trindade, C. S. (2013). Technologica Challenges for Spray Chilling Encapsulation of Functional Food Ingredients. Food Technology and Biotechnology, 51, 171-182.

Okuro, P. K., Thomazini, M., Balieiro, J. C. C., Liberal, R. D. C. O., \& FávaroTrindade, C. S. (2013). Co- encapsulation of Lactobacillus acidophilus with inulin or polydextrose in solid lipid microparticles provides protection and improves stability. Food Research International, 53, 96-103. https://doi.org/10.1016/j.foodres.2013.03.042

Oliveira, a C., Moretti, T. S., Boschini, C., Baliero, J. C. C., Freitas, O., \& Favaro-Trindade, C. S. (2007). Stability of microencapsulated B. lactis (BI 01) and L. acidophilus (LAC 4) by complex coacervation followed by spray drying. Journal of Microencapsulation, 24(7), 673-681. https://doi.org/10.1080/07373930701590939

Paz, N. F., Oliveira, E. G. de, Kairuz, M. S. N. de, \& Ramón, A. N. (2014) Characterization of goat milk and potentially symbiotic non-fat yogurt. Food Science and Technology (Campinas), 34, 629-635. http://dx.doi.org/10.1590/1678-457x.6409

Pedroso, D. de L., Thomazini, M., Heinemann, R. J. B., \& Favaro-Trindade, C. S (2012). Protection of Bifidobacterium lactis and Lactobacillus acidophilus by microencapsulation using spray-chilling. International Dairy Journal, 26, 127 132. https://doi.org/10.1016/j.idairyj.2012.04.008

Pedroso, D. L., Dogenski, M., Thomazini, M., Heinemann, R. J. B., \& FavaroTrindade, C. S. (2013). Microencapsulation of Bifidobacterium animalis subsp lactis and Lactobacillus acidophilus in cocoa butter using spray chilling technology. Brazilian Journal of Microbiology, 44, 777-783.

Pelletier, C., Bouley, C., Cayuela, C., Bouttier, S., Bourlioux, P., \& BellonFontaine, M. N. (1997). Cell surface characteristics of Lactobacillus casei subsp. casei, Lactobacillus paracasei subsp. paracasei, and Lactobacillus rhamnosus strains. Applied and Environmental Microbiology, 63(5), 1725-1731.

Pimentel-González, D. J., Campos-Montiel, R. G., Lobato-Calleros, C., PedrozaIslas, R., \& Vernon-Carter, E. J. (2009). Encapsulation of Lactobacillus rhamnosus in double emulsions formulated with sweet whey as emulsifier and survival in simulated gastrointestinal conditions. Food Research International, 42(2), 292-297. https://doi.org/http://dx.doi.org/10.1016/j.foodres.2008.12.002

Polak-Berecka, M., Waśko, A., Paduch, R., Skrzypek, T., \& Sroka-Bartnicka, A (2014). The effect of cell surface components on adhesion ability of Lactobacillus rhamnosus. Antonie Van Leeuwenhoek, 106, 751-762. https://doi.org/10.1007/s10482-014-0245-x

Poppi, L. B., Rivaldi, J. D., Coutinho, T. S., Astolfi-Ferreira, C. S., Ferreira, A. J P., \& Mancilha, I. M. (2015). Effect of Lactobacillus sp. isolates supernatant on Escherichia coli O157:H7 enhances the role of organic acids production as a factor for pathogen control. Pesquisa Veterinária Brasileira, 35, 353-359. http://dx.doi.org/10.1590/S0100-736X2015000400007.

Rabia, A., \& Shah, N. P. (2011). Antibiotic resistance of probiotic organisms and safety of probiotic dairy products. International Food Research Journal.

Rosenberg, M., Gutnick, D., \& Rosenberg, E. (1980). Adherence of bacteria to hydrocarbons: A simple method for measuring cell-surface hydrophobicity. FEMS Microbiology Letters, 9(1), 29-33. https://doi.org/10.1111/j.15746968.1980.tb05599.x

Röytiö, H., \& Ouwehand, A. C. (2014). The fermentation of polydextrose in the large intestine and its beneficial effects. Beneficial Microbes, 5(3), 305-313. https://doi.org/10.3920/BM2013.0065

Saarela, M., Mogensen, G., Fondén, R., Mättö, J., \& Mattila-Sandholm, T. (2000). Probiotic bacteria: Safety, functional and technological properties Journal of Biotechnology. https://doi.org/10.1016/S0168-1656(00)00375-8

Saha, S., Tomaro-Duchesneau, C., Daoud, J. T., Tabrizian, M., \& Prakash, S (2013). Novel probiotic dissolvable carboxymethyl cellulose films as oral health biotherapeutics: in vitro preparation and characterization. Expert Opinion on Drug Delivery, 10(11) $1471-1482$ https://doi.org/10.1517/17425247.2013.799135

Saha, S., Tomaro-Duchesneau, C., Tabrizian, M., \& Prakash, S. (2012) Probiotics as oral health biotherapeutics. Expert Opinion on Biological Therapy, 12(9), 1207-1220. https://doi.org/10.1517/14712598.2012.693474

SALMINEN, S., LAINE, M., VONWRIGHT, A., VUOPIO-VARKILA, J., KORHONEN, T., \& MATTILA-SANDHOLM, T. (1996). Development of Selection Criteria for Probiotic Strains to Assess Their Potential in Functional Foods: A Nordic and European Approach. Bioscience and Microflora, 15(2), 6167. https://doi.org/10.12938/bifidus1996.15.61

Santos, T. T., Santos Ornellas, R. M., Borges Arcucio, L., Messias Oliveira, M., Nicoli, J. R., Villela Dias, C., ... Vinderola, G. (2016). Characterization of lactobacilli strains derived from cocoa fermentation in the south of Bahia for the development of probiotic cultures. LWT - Food Science and Technology, 73, 259-266. https://doi.org/http://dx.doi.org/10.1016/j.lwt.2016.06.003

Schieber, A. (2012). Functional Foods and Nutraceuticals. Food Research International, $46(2)$,

https://doi.org/https://doi.org/10.1016/j.foodres.2012.02.009

Schillinger, U., \& Lücke, F.-K. (1987). Identification of lactobacilli from meat and meat products. Food Microbiology, 4(3), 199-208. https://doi.org/http://dx.doi.org/10.1016/0740-0020(87)90002-5

Sharma, M., \& Devi, M. (2014). Probiotics: a comprehensive approach toward health foods. Critical Reviews in Food Science and Nutrition, 54(4), 537-52. https://doi.org/10.1080/10408398.2011.594185

Sharma, P., Tomar, S. K., Goswami, P., Sangwan, V., \& Singh, R. (2014) Antibiotic resistance among commercially available probiotics. Food Research International, 
lactobacilli and bifidobacteria. Journal of Applied Microbiology, 114(4), 1132

1146. https://doi.org/10.1111/jam.12105

$\mathrm{Xu}$, H., Jeong, H. S., Lee, H. Y., \& Ahn, J. (2009). Assessment of cell surface properties and adhesion potential of selected probiotic strains. Letters in Applied Microbiology, 49(4), 434-442. $\quad$ https://doi.org/10.1111/j.1472 765X.2009.02684.X

Ya, T., Zhang, Q., Chu, F., Merritt, J., Bilige, M., Sun, T., ... Zhang, H. (2008) Immunological evaluation of Lactobacillus casei Zhang: a newly isolated strain from koumiss in Inner Mongolia, China. BMC Immunology, 9(1), 68 https://doi.org/10.1186/1471-2172-9-68

Zago, M., Fornasari, M. E., Carminati, D., Burns, P., Suàrez, V., Vinderola, G., ... Giraffa, G. (2011). Characterization and probiotic potential of Lactobacillus plantarum strains isolated from cheeses. Food Microbiology, 28(5), 1033-1040. https://doi.org/http://dx.doi.org/10.1016/j.fm.2011.02.009 